ZOOLOGIA 30 (6): 639-644, December, 2013

http://dx.doi.org/10.1590/S1984-46702013005000009

\title{
Temporal variations of Collembola (Arthropoda: Hexapoda) in the semiarid Caatinga in northeastern Brazil
}

\author{
Aila Soares Ferreira1, Bruno Cavalcante Bellini ${ }^{1} \&$ Alexandre Vasconcellos ${ }^{2,3}$
}

\author{
1 Programa de Pós-graduação em Sistemática e Evolução, Departamento de Botânica, Ecologia e Zoologia, Centro de \\ Biociências, Universidade Federal do Rio Grande do Norte. Lagoa Nova, Campus Universitário, 59072-970 Natal, RN, Brazil. \\ ${ }^{2}$ Laboratório de Termitologia, Departamento Sistemática e Ecologia, Universidade Federal da Paraíba. 58051-900 João \\ Pessoa, PB, Brazil. \\ ${ }^{3}$ Corresponding author: avasconcellos@dse.ufpb.br
}

\begin{abstract}
The richness and abundance of Collembola species can be influenced by many biotic and abiotic factors, mainly humidity. The semiarid region of Brazil is dominated by Caatinga dryland vegetation which experiences distinct seasonal alterations of its physiognomy linked to regional rainfall regimes. The present study evaluated the environmental factors affecting populations of Collembola in an area of Caatinga vegetation in Northeastern Brazil during a 12 months period. Specimens were collected by active searching in ten $20 \times 20$ m plots, with a sampling effort of 1 hour/ person/plot. A total of 1231 specimens were collected, comprising 15 morphospecies, 12 genera, and nine families. Both species richness and individual abundances demonstrated oscillations during the year, with the highest values occurring during the rainy season; rainfall was the principal predictive variable for the observed temporal oscillations. Minimum temperatures and precipitation influenced the structural composition of the Collembola. Populations of Collembola demonstrated clustered distribution during the year. The direct and indirect effects of precipitation on the quality of microhabitats and resource availability were apparently responsible for the numerical and compositional alterations of the Collembola fauna observed in the Caatinga site.
\end{abstract}

KEY WORDS. Abundance; climatic variables; edaphic fauna; seasonality; species richness.

Collembola are abundant representatives of the pedofauna (CASSAGNe et al. 2003) and have important roles in soil formation and decomposition of organic material (making it more easily degraded by fungi and bacteria) (Hopkins 1997, ZeppeLINI $\&$ BelLini 2004). The abundance and richness of Collembola species are influenced by various biotic and abiotic factors (CuLIK \& Zeppelini 2003, Zeppelini et al. 2009), and the abundances of individuals in numerous insect orders are known to be related to temporal variations in climatic conditions in both temperate and tropical ecosystems (WoLDA 1988).

Seasonal variations in insect abundances are a common phenomenon, with accentuated reductions in abundance being common during the dry seasons in tropical regions or during the winter in temperate regions (Wolda 1988, Pinheiro et al. 2002, VASCONCELLos et al. 2010). Climatic variables such as rainfall, humidity, and temperature are known to be good indicators of the activity (and/or reproductive activities) of insect populations in environments where there are clear distinctions between rainy and dry seasons (JANZEN 1973, WoLDA 1978). Other factors, however, may influence the seasonal activities of insect species inhabiting tropical regions, such as variations in the availability of food resources, interspecific competition, and habitat variations (WOLDA 1988).
The Caatinga (Seasonal Dry Forest) biome comprises an area of approximately $740,000 \mathrm{~km}^{2}$ in Northeastern Brazil, about $10 \%$ of the surface area of the country (Tabarelli \& Silva 2003 ). From $50 \%$ to $70 \%$ of the annual precipitation in almost all Caatinga region is concentrated into three consecutive months - characterizing an extremely seasonal climate with a long dry season varying from six to nine months but extending to 10 or even 11 months in some of the driest regions (NIMER 1972). As such, the concentration of rainfall into short periods of time (intercalated by long dry seasons) exercises more accentuated effects on living organisms than the actual total amount of precipitation. The Caatinga biome comprises a surprising diversity of environments, constituting a mosaic of vegetation types ranging from dry forests to open formations dominated by cacti and bromeliads that all demonstrate accentuated leaf fall during the dry season (Tabarelli \& Silva 2003).

Studies of the effects of temporal variations of climatic factors on the Caatinga fauna, especially in terms of its invertebrates, have been scarce in light of the wide diversity of this group of organisms (Aguiar \& Martins 1997, Zanella \& Martins 2003, Gusmão \& Creão-Duarte 2004, Iannuzzi et al. 2006, Hernández 2007, Araújo et al. 2010, Vasconcellos et al. 2010, Medeiros et al. 2012) 
The present study sought to evaluate the Collembola fauna in a semiarid area of Caatinga vegetation in northeastern Brazil and identify the climatic variables that influence species richness, individual abundances, and the structural composition of that guild. This represents one of the few studies undertaken in the Caatinga biome that has evaluated the effects of temporal variations in climatic elements on invertebrates at the species level.

\section{MATERIAL AND METHODS}

Collections were undertaken in a preserved area of Caatinga vegetation (approximately 100 years without the removal of any woody material) at the Fazenda Cauaçu farm $\left(05^{\circ} 32^{\prime} 15^{\prime \prime} \mathrm{S}, 35^{\circ} 49^{\prime} 11^{\prime \prime} \mathrm{W}\right)$ in the municipality of João Câmara, state of Rio Grande do Norte, Brazil. The regional climate is semiarid, with an average and a rainfall of $648.6 \mathrm{~mm}$. The rainy season normally lasts from March to June. The average annual temperature is $24.7^{\circ} \mathrm{C}$, with a minimum of $21^{\circ} \mathrm{C}$ and maximum of $32^{\circ} \mathrm{C}$. The caatinga vegetation there includes shrub and arboreal physiognomies (IDEMA 2011).

Collections were made on a monthly basis for a full year (August/2011 to July/2012) in ten $20 \times 20 \mathrm{~m}$ plots that were established at random in an area of 25 ha $(500 \times 500 \mathrm{~m})$. The Collembola were harvested with a collection effort of 1 hour/ person/plot in diverse microhabitats (such as the leaf litter, soil, and on tree bark) using a white tray and an entomological aspirator; the specimens were subsequently fixed in $70 \%$ ethanol.

The specimens collected were examined and counted under a stereomicroscope, cleared in 5\% $\mathrm{KOH}$ and lactophenol, and mounted on semi-permanent slides for microscopic observation in Hoyer's medium (Christiansen \& Bellinger 1998). We also employed the clearing methodology described by ARLÉ \& MendonçA (1982), using hydrochloric acid (HCL) and potassium dichromate. Species identifications were made through morphological and chaetotaxic studies of the specimens using an optical microscope with the aid of specialized keys for identifying families, genera, and species.

Multiple regression analyses were performed using species richnesses and individual abundances (dependent variables), with four independent variables: rainfall, maximum and minimum temperatures, and relative humidity of the air. Climatic data was provided by EMPARN (Empresa de Pesquisa Agropecuária do Rio Grande do Norte). The Durbin-Watson test was used to verify the temporal independence of the samples by examining the existence (or not) of autocorrelations among the residual values (DURBIN \& WATSON 1950). Regression analyses at species level were only performed with species encountered in at least five monthly samples.

Based on the distance matrix, obtained from the BrayCurtis coefficient, non-metric multidimensional scaling was undertaken (NMDS) to calculate the distortion (or stress) between the similarity matrix and the ordination, producing a graph whose axes could be used to evaluate the spatial disposi- tion of the guild in two dimensions for each month (MANLY 2008). Pearson's correlation analyses were subsequently undertaken using the environmental variables and the values of the two principal NMDS axes to determine which variables most influenced the compositional structure of the Collembola guild.

Rayleigh's test was used to determine if the distributions of the annual abundances of the Collembola guild, and of the most frequent species, were random (ZAR 1999). All of the analyses were performed using R program software (R Core Team, 2012), including the Car (Fox \& Weisberg 2011), Circular (Agostinelli \& Lund 2011), Vegan (Oksanen et al. 2012) and MASS (Venables \& Ripley 2002) packages.

\section{RESULTS}

During the 12 study months a total of 1,231 Collembola specimens were collected, comprising 15 morphospecies in 12 genera, and nine families (Table I). Of the 12 genera identified, only Seira Lubbock, 1869 was represented by more than a single species (four species); it was also the most abundant genus, with 986 specimens ( $80 \%$ of the total abundance). Seira sp. 2 was the most abundant species (708 specimens; $57.5 \%$ of the total abundance), followed by Seira sp. 1 (259 specimens; $21 \%$ of the total abundance), and Brachystomella sp. (124 specimens; $10 \%$ of the total abundance). The other species demonstrated abundance values of $>10 \%$ of the total (Table I). The species Seira sp. 1, Seira sp. 2, and Seira sp. 3 were the most frequent, while the remaining species were encountered in fewer than five collection months (Table I).

The climatic variable rainfall explained $59 \%$ of the temporal variations of species richness and $58 \%$ of the variations of abundance of Collembola (Table II). There was no temporal autocorrelation between the regression residuals $\left(\mathrm{DW}_{\text {richness }}=\right.$ $1.87, \mathrm{p}=0.22 ; \mathrm{DW}_{\text {abundance }}=2.64, \mathrm{p}=0.91$ ). The temporal variations of the species Seira sp. 1, Seira sp. 2, and Seira sp. 3 were explained by temperature variations.

The structural composition of the Collembola assemblage was also influenced by temporal variations of climatic elements (Fig. 1 and Table III). Axis 1 of the NMDS was related to the minimum temperature, while axis 2 was principally related to rainfall.

The distributions of the abundances of Collembola individuals during the 12 months were different from random distributions $(\mathrm{z}=0.618, \mathrm{p}=0.007)$, being concentrated during the rainy period. Clustered distributions were also observed for Seira sp. $1(\mathrm{z}=0.513, \mathrm{p}=0.038)$, Seira sp. $2(\mathrm{z}=0.695, \mathrm{p}=$ $0.001)$, and Seira sp. $3(\mathrm{z}=0.857, \mathrm{p}=0.000)$

\section{DISCUSSION}

Twenty-nine species of Collembola have been reported from areas of Caatinga vegetation in Brazil, including the results of the present study (BELLINI \& ZepPeLINI 2009, SANTos-Rocha et al. 2011). The species richness of Collembola in this biome 
Table I. The diversity of Collembola captured between August/2011 and July/2012 at the Fazenda Cauaçu farm, João Câmara, Rio Grande do Norte, Brazil.

\begin{tabular}{|c|c|c|c|c|c|c|c|c|c|c|c|c|c|}
\hline Family/Species & Aug/11 & Sep/11 & Oct/11 & Nov/11 & $\mathrm{Dec} / 11$ & Jan/12 & Feb/12 & Mar/12 & Apr/12 & May/12 & Jun/12 & Jul/12 & Tota \\
\hline \multicolumn{14}{|l|}{ Neanuridae } \\
\hline Arlesia alpibes & 7 & - & - & - & - & - & - & - & - & - & - & - & 7 \\
\hline Brachystomella sp. & 10 & - & - & - & - & 3 & - & - & - & - & - & 111 & 124 \\
\hline \multicolumn{14}{|l|}{ Entomobryidae } \\
\hline Seira sp. 1 & 100 & 91 & 17 & 8 & 8 & 9 & - & - & - & - & 1 & 25 & 259 \\
\hline Seira sp. 2 & 35 & 15 & 5 & 17 & 29 & 6 & 50 & 54 & 256 & 48 & 40 & 153 & 708 \\
\hline Seira sp. 3 & 3 & - & 4 & - & 4 & 3 & - & - & 1 & - & - & - & 15 \\
\hline Seira sp. 4 & 4 & - & - & - & - & - & - & - & - & - & - & - & 4 \\
\hline Pseudosinella aff. octopunctata & 16 & - & - & - & - & - & - & - & - & - & - & 2 & 18 \\
\hline \multicolumn{14}{|l|}{ Isotomidae } \\
\hline Desoria sp. & - & - & - & - & - & - & - & 3 & - & - & - & 1 & 4 \\
\hline \multicolumn{14}{|l|}{ Paronellidae } \\
\hline \multicolumn{14}{|l|}{ Sminthuridae } \\
\hline Temeritas sp. & 8 & - & - & - & - & - & - & - & - & - & - & 1 & 9 \\
\hline Sphyrotheca sp. & 15 & - & - & - & - & - & - & 7 & - & - & - & 1 & 23 \\
\hline \multicolumn{14}{|l|}{ Sminthurididae } \\
\hline Sphaeridia sp. & - & - & - & - & - & - & - & - & - & - & - & 3 & 3 \\
\hline \multicolumn{14}{|l|}{ Bourletiellidae } \\
\hline Bourletiellidae sp. & - & - & - & - & - & - & - & - & - & - & - & 3 & 3 \\
\hline Stenognathriopes sp. & - & - & - & - & - & - & - & 8 & 3 & - & 1 & 14 & 26 \\
\hline \multicolumn{14}{|l|}{ Dicyrtomidae } \\
\hline Dicyrtoma sp. & 20 & - & - & - & - & - & - & 2 & - & - & - & 1 & 23 \\
\hline Total of specimens & 223 & 106 & 26 & 25 & 41 & 21 & 50 & 74 & 260 & 48 & 42 & 315 & 1231 \\
\hline Total richness & 11 & 2 & 3 & 2 & 3 & 4 & 1 & 5 & 3 & 1 & 3 & 11 & - \\
\hline
\end{tabular}

Table II. Multiple regression analysis of the richnesses and abundances of Collembola species captured in João Câmara, RN, with climatic variables. Regressions at the species level were only performed for species encountered during at least five months.

\begin{tabular}{lcccccc}
\hline \multirow{2}{*}{ Collembola } & \multirow{2}{*}{$\mathrm{R}_{\text {adj }}$} & F-value & \multicolumn{3}{c}{ Climatic Variables } & \multirow{2}{*}{ P-value } \\
\cline { 4 - 5 } & & & Precipitation & T. max & T. min & \\
\hline Richness & 0.59 & 19.03 & 2.24 & & 0.003 \\
Abundance & 0.58 & 12.62 & 1.52 & & & 0.009 \\
Seira sp. 1 & 0.73 & 12.70 & & -1.56 & & 0.009 \\
Seira sp. 2 & 0.36 & 5.58 & & & 0.81 & 0.050 \\
Seira sp. 3 & 0.21 & 6.60 & & 1.23 & 0.037 \\
\hline
\end{tabular}

Table III. Pearson's Correlation between environmental variables and the NMDS scores of the Collembola guild in João Câmara, Rio Grande do Norte, Brazil. * $p<0.05$

\begin{tabular}{lcc}
\hline \multicolumn{1}{c}{ Climatic Variables } & Axis 1 (NMDS) & Axis 2 (NMDS) \\
\hline Precipitation & -0.22 & $0.85^{*}$ \\
Relative humidity & -0.47 & $-0.82^{*}$ \\
Minimum temperature & $0.68^{*}$ & 0.43 \\
Maximum temperature & -0.17 & $0.81^{*}$ \\
\hline
\end{tabular}

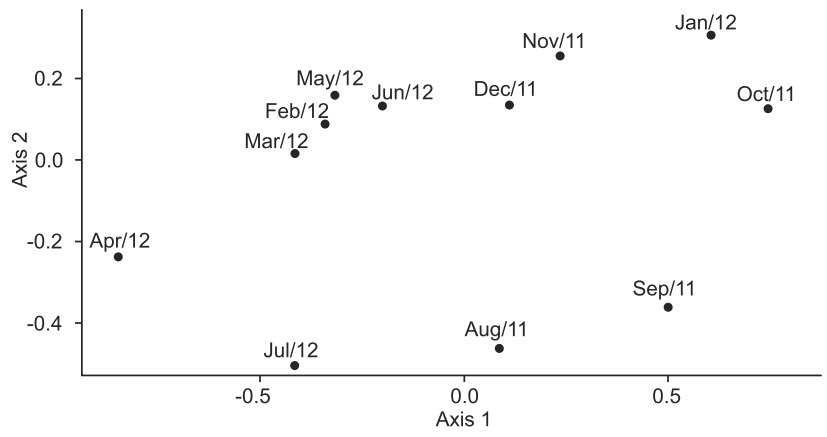

Figure 1. NMDS analysis generated by Bray-Curtis similarity matrices of the Collembolan fauna at João Câmara, Rio Grande do Norte, Brazil.

must certainly be much greater, as only limited studies have been undertaken in the "Depressão Sertaneja Setentrional" ecoregion (among seven recognized ecoregions with unique climatic, geomorphological, and vegetational conditions) (VeLLoso et al. 2002). 
The Collembola species identified in the present study demonstrated seasonal patterns of abundance, with their distributions being grouped during the rainy season. According to WoLDA (1978), areas with well-defined rainfall cycles tend to have less abundant insect populations during the dry season, as has been reported for various groups of Caatinga insects (IANnuzz et al. 2006, VAsCONCELlos et al. 2010). The structural composition of the entire Collembola assemblage (and not just the individual species and their individual abundances) was found to be greatly influenced by direct and indirect effects of climatic variables.

Insect assemblages in Neotropical ecosystems are strongly influenced by rainfall (Wolda 1978, Develey \& Peres 2000, HERNÁNDEZ 2007), and the patterns of abundance and richness observed in the present study among Collembola species were explained principally by this same phenomenon. VASCONCELLOS et al. (2010) investigated the effects of seasonal change on various insect orders in the Caatinga region and observed that their abundance patterns were principally related to rainfall patterns. Temperature, on the other hand, appears to be the environmental variable that most affects insect guilds in the Cerrado (Brazilian savanna) biome (SILVA 2011).

The responses of the Collembola assemblage to rainfall in the Caatinga region are probably related to corresponding responses by the vegetation, as the plants there renew their growth activities rapidly after the first rains - resulting in greater food resource availability (and a more amenable climate) (Machado et al. 1995). According to Castaño-Meneses et al. (2004), decomposing organic plant material is the principal dietary resource of Collembolans, followed by fungi (conidia and spores) and, occasionally, other animals (possibly already dead) such as dust mites and even other Collembola. Resource availability plays an important role in determining the seasonal abundance patterns of insects, as food resources vary with the seasonal climate (WoLDA 1978, 1988).

Collembola have low natural resistance to desiccation (BUTCHER et al. 1971) and reductions in substrate humidity constitute a determinant factor in their population densities during the dry season. Reduced mite activity is not necessarily linked to mortality, however, as population decreases may be related to other behavioral survival mechanisms such as reductions in reproduction rates or the migration of individuals to more humid localities (Butcher et al. 1971). It is possible that certain microhabitats can serve as refuges for these mites during the dry season. Leaf litter, fallen trunks, and rocky soils provide important microhabitats for the pedofauna due to their ability to maintain acceptable levels of soil humidity during the dry season (Goldsbrough et al. 2003), allowing these hexapods to survive and subsequently increase their horizontal distributions in the soil and occupy additional microhabitats at the beginning of the rainy season, where they can mate, lay their eggs, and find food and protection against predators (CoRNelissen \& BOECHAT 2001).

Seira was the most abundant genus and the only one represented by more than a single species. The species of this genus are predominately tropical and are covered by abundant hairs and scales that can trap layers of air above their bodies, diminishing water losses and allowing these animals to inhabit dry environments (Christiansen \& Bellinger 2000, Zeppelini \& BELLINI 2004). BeLLINI \& ZEPPELINI (2009) noted that northeastern Brazil has one of the highest species richnesses of this genus in the world. Twenty-five species of Seira have been reported from Brazil, with 14 recorded in the Caatinga region (BelLINI \& Zeppelini 2009, SANTos-Rocha et al. 2011).

The numerical variations in the populations of Seira sp. 1, Seira sp. 2, and Seira sp. 3 were explained by temperature variations. Environmental factors, especially temperature, directly affect development among Collembolans, with their growth rates being suppressed during unfavorable seasons; there are many examples of the eggs and immatures of this guild surviving unfavorable periods through latency or diapause (CHRISTIANSEN \& Bellinger 1988, Hopkins 1997, Bellinger et al. 1996-2012).

Seira sp. 2 was the most frequent and abundant species during the dry season, with a seasonal pattern similar to that reported for Seira purpurea Schött, 1891 in Mexico (PALAciosVARGAS et al. 2003). S. purpurea has been observed varying its diet between the dry and rainy seasons, with fragments of Collembola and other nematode parasites being found in their intestines during the dry season (CASTAÑo-MENESES et al. 2004). Collembola are considered generalist consumers and can use many food resources, depending on their habitats. The high abundance and frequency of Seira sp. 2 during the dry season may also be related to reductions in some groups of insect predators. Collembola have many natural enemies, including Coleoptera (such as carabid beetles and their larva), Diptera, and Hymenoptera (Rusek 1988). VAsConcellos et al. (2010) reported that the abundances of these predator groups were greatly reduced during the dry season.

The present study demonstrated that the return of rainfall to the Caatinga region was directly related to increases in the richness and abundance of Collembolans, although other factors such as interspecific competition, predation, and the distribution of food resources during the year act in tandem with climatic factors to influence the distributions of Collembola.

The effects of climatic variables on Collembola suggest that future climate changes (principally in terms of rainfall patterns and temperature regimes) will affect ecosystems services directly or indirectly associated with these organisms. Collembola are one of the least known groups among the hexapods that compose the Caatinga pedofauna, principally in terms of their spatial-temporal distributions and diversity.

\section{ACKNOWLEDGEMENTS}

We thank Uirande Oliveira, Pedro Capistrano, Daniel Oliveira, Nicolas de Araújo, Heitor Bruno, Thiago Felipe, and Nerivania Godeiro for help in the field. The senior author was a fellow of CAPES. 


\section{LITERATURE CITED}

Agostinelli, C. \& U. Lund. 2011. R package 'circular': Circular Statistics. Avalable online at: https://r-forge.r-project.org/ projects/circular [Accessed: 03/VI/2012].

Aguiar, C.M.L. \& C.F. Martins. 1997. Abundância relativa, diversidade e fenologia de abelhas (Hymenoptera, Apoidea) na Caatinga, São João do Cariri, Paraíba, Brasil. Iheringia, Série Zoologia, 83: 151-163.

Araújo, C.S.; D.M. Candido; H.F.P. Araújo; S.C. Dias \& A. VASCONCELLOS. 2010. Seasonal variations in scorpion activities (Arachnida: Scorpiones) in an area of Caatinga vegetation in northeastern Brazil. Zoologia 27: 372-376. doi: 10.1590/ S1984-46702010000300008.

ArLé, R. \& C. MendonçA. 1982. Estudo preliminar das espécies de Dicranocentrus Schött, 1893, ocorrentes no Parque Nacional da Tijuca, Rio de Janeiro (Collembola). Revista Brasileira de Biologia 42 (1): 41-49.

Bellinger, P. F.; K. A. Christiansen \& F. Janssens. 1996-2012. Checklist of the Collembola of the World. Available online at: http://www.collembola.org. [Accessed: 03/VI/2012].

Bellini, B. C. \& D. Zeppelini. 2009. Registros da fauna de Collembola (Arthropoda, Hexapoda) no Estado da Paraíba, Brasil. Revista Brasileira de Entomologia 53 (3): 386-390.

ButcherJ, W.; R. SNider \& R.J. SNider. 1971. Bioecology of edaphic Collembola and Acarina. Annual Review of Entomology 3: 249-288.

Cassagne, N.; C. Gers \& T. Gauquelin. 2003. Relationships between Collembola, soil chemistry and humus types in forest stands (France). Biology and Fertility of Soils 37: 355-361. doi: 10.1007/s00374-003-0610-9.

Castaño-Meneses, G.; J.G. Palacios-Vargas \& L.Q. Cutz-Pool. 2004. Feeding habits of Collembola and their ecological niche. Anales del Instituto de Biologia, Universidad Nacional Autónoma de México, Serie Zoologia 75 (1): 135-142.

Christiansen, K. \& P. Bellinger. 1998. The Collembola of North America. North of Rio Grande, an analysis taxonomic. Iowa: Grinnel College: 1322-1980.

Christiansen, K.A. \& P. Bellinger. 2000. A Survey of the Genus Seira (Hexapoda: Collembola: Entomobryidae). SciencesNew York 36 (1): 39-75.

Cornelissen, T.G. \& I.G. Boechat. 2001. Seleção de hábitats por Porrimosa lagotis (Mello-Leitão, 1941) (Araneae, Lycosidae) em área de cerrado em Minas Gerais, Brasil. Revista Brasileira de Zoociências 3 (2): 147-1548.

Culik, M.P. \& D. Zeppelini. 2003. Diversity and distribution of Collembola (Arthropoda: Hexapoda) of Brazil. Biodiversity and Conservation 12: 1119-1143.

Develey, P.F. \& C.A. Peres. 2000. Resource seasonality and the structure of mixed species bird flocks in a coastal Atlantic forest of southeastern Brazil. Journal of Tropical Ecology 16: 33-53.

Durbin, J. \& G.S. WATSON. 1950. Testing for serial correlation in least squares regression. Biometrika 37: 409-428.
Fox, J. \& S.Weisberg. 2011. An R Companion to Applied Regression. Thousand Oaks, Sage. Available online at: http:/ /socserv.socsci.mcmaster.ca/jfox/Books/Companion [Accessed: 03/VI/2012].

Goldsbrough, C.L.; D.F. Hochuli \& R. Shine. 2003. Invertebrate biodiversity under hot rocks: habitat use by the fauna of sandstone outcrops in the Sydney region. Biological Conservation 109: 85-93.

Gusmão, M.A.B. \& A.J. CReão-Duarte. 2004. Diversidade e análise faunística de Sphingidae (Lepidoptera) em área de brejo e caatinga no Estado da Paraíba, Brasil. Revista Brasileira de Zoologia 21: 491-498.

Hernandez, M.I.M. 2007. Besouros escarabeineos (Coleóptera: Scarabaeidae) da caatinga paraibana, Brasil. Oecologia Brasiliensis 11: 356-364.

HopкIN, S.P. 1997. Biology of Springtails (Insecta: Collembola). New York, Oxford University Press, 344p.

IANNUZZI, L.; A.C.D. MaIA \& S.D. VASCONCelos. 2006. Ocorrência e sazonalidade de coleópteros buprestídeos em uma região de caatinga nordestina. Biociências 14: 174-179.

IDEMA. Informativo municipal, João Câmara. Instituto de Desenvolvimento Sustentável e Meio Ambiente do Rio Grande do Norte. Available online at: http://200.149.240.140:8080/ i3geo/aplicmap/geral.htm?109e26d9b378612b42a08fd 20675547d\#> [Accessed: 08/03/2011].

JANZEN, D.H. 1973. Sweep samples of tropical foliage insects: effects of seasons, vegetation types, elevation, time of day, and insularity. Ecology 54: 667-701.

Machado, I.C.S.; L.M. Barros \& E.V.S.B. SampaIo. 1995. Phenology of Caatinga Species at Serra Talhada, PE, Northeastern Brazil. Biotropica 29: 57-68.

MANLY, B.J.F. 2008. Métodos estatísticos multivariados: uma introdução. Porto Alegre, Bookman, $3^{\text {rd }}$ ed., 229p.

Medeiros, J.; A. Araujo; H.P.F. Araujo; J.P.C. Queiroz \& A. Vasconcellos. 2012. Seasonal activity of Dinoponera quadriceps (Formicidae, Ponerinae) in the semi-arid Caatinga of northeastern Brazil. Revista Brasileira de Entomologia 56: 81-85.

Nimer, E. 1972. Climatologia da região Nordeste do Brasil. Introdução à climatologia dinâmica. Revestia Brasileira Geografia 34: 3-51.

Oksanen, F.J.; B. Guillaume; K. Roeland; L. Pierre; R.M. Peter; R.B. O'Hara; L.S. Gavin; S. Peter; M.H.H. Stevens \& H. Wagner. 2012. Vegan: Community Ecology Package. R package version 2.0-5. Available online at: http://CRAN.R-project.org/package = vegan [Accessed: Accessed: 03/VI/2012].

Palacios-Vargas, J.G. \& G. Castaño-Meneses. 2003. Seasonality and community composition of springtails in Mexican forests, p. 159-169. In: Y. BASSET; R. Kitching, S. Miller \& N. Novotny (Eds). Arthropods of tropical forests. Cambridge, Cambridge University Press.

Pinheiro, F.; I.R. Diniz; D. Coelho \& M.P.S. Bandeira. 2002. Seasonal pattern of insect abundance in the Brazilian Cerrado. Austral Ecology 27: 132-136. 
R Core Team. 2012. R: A language and environment for statistical computing. R Foundation for Statistical Computing, Vienna, Austria. ISBN 3-900051-07-0, available online at: http://www.R-project.org.

Ruser, J.1998. Biodiversity of Collembola and their functional role in the ecosystem. Biodiversity and Conservation 7: 1207-1219

Santos-Rocha, I.M.; R. Andreazze \& B.C. Bellini. 2011. Registros de Collembola (Arthropoda, Hexapoda) no Estado do Rio Grande do Norte, Brasil. Biota Neotropica 11 (3): 167-170.

Silva, N.A.P.; M.R. Frizzas \& C.M. Oliveira. 2011. Seasonality in insect abundance in the "Cerrado" of Goiás State, Brazil. Revista Brasileira de Entomologia 55 (1): 79-87.

TABARELl, M \& J.M.C. Silva. 2003. Áreas e ações prioritárias para a conservação da biodiversidade da Caatinga, p. 777-796. In: I.R. Leal; M. Tabarelli \& J.M. C Silva (Eds). Ecologia e Conservação da Caatinga. Recife, Universidade Federal de Pernambuco.

Vasconcellos, A.; R. Andreazze; A.M. Almeida; H.F.P.Araujo; E. S. Oliveira \& U. Oliveira. 2010. Seasonality of insects in the semi-arid Caatinga of northeastern Brazil. Revista Brasileira de Entomologia 54: 471-476.

Velloso, A.L.; E.V.S.B. Sampaio \& F.G.C. Pareyn. 2002. Ecorregiões propostas para o Bioma Caatinga. Resultados do Semi- nário de Planejamento Ecorregional da Caatinga. Recife, Associação Plantas do Nordeste, The Nature Conservancy do Brasil.

Venables, W.N. \& B.D. Ripley. 2002. Modern Applied Statistics with S. New York, Springer, $4^{\text {th }}$ ed.

Wolda, H. 1978. Seasonal fluctuations in rainfall, food and abundance of tropical insects. Journal Animal Ecology 47: 369-381.

Wolda, H. 1988. Why Insect seasonality? Annual Review of Ecology and Systematics PaloAlto 19: 1-18.

Zanella, F.C.V. \& C.F. Martins. 2003. Abelhas da Caatinga: Biogeografia, Ecologia e Conservação, p. 75-134. In: I. LEAL; M. Tabarelli \& J. M. C. Silva (Eds). Ecologia e conservação da Caatinga. Recife, Universidade Federal de Pernambuco, 804p.

ZAR, J. H. 1999. Biostatistical Analysis. New Jersey, Prentice Hall, $663 p$.

Zeppelini, D.F. \& B.C. Bellini. 2004. Introdução ao estudo dos Collembola. João Pessoa, Editora Universitária, Universidade Federal da Paraíba, 82p.

Zeppelini, D.; B.C. Bellin;; A.J. Creão-Duarte \& M.I.M. Hernández. 2009. Collembola as bioindicators of restoration in mined sand dunes of Northeastern Brazil. Biodiversity and Conservation 18: 1161-1170. doi: 10.1007/s10531-008-9505-2.

Submitted: 11.VI.2013; Accepted: 13.IX.2013.

Editorial responsibility: Antonio D. Brescovit 